\title{
An Empirical Study of the Impact of Intellectual Capital on the Financial Performance of the Indian IT Sector
}

\author{
Khan, Ahmed Musa \\ $\mathrm{PhD}$ in Commerce \\ Aligarh Muslim University, \\ Aligarh - 202002, Uttar Pradesh, India \\ E-mail:musa.mfc@gmail.com; musakhan.rs@amu.ac.in
}

\begin{abstract}
In the present scenario, intellectual capital has been established as an important corporate asset because conventional performance measurement techniques are incapable of measuring the intangible dimensions of corporate performance. It is a challenge, especially for knowledge driven firms, to measure the impact of intangibles on their financial performance. The main objective of this study is to show the impact of intellectual capital on the financial performance of the Indian IT sector. In order to conduct the study, the sample was drawn from the IT sector for which the sector index of BSE, namely the BSE IT, had been selected. In all,data from 51 companies from the Information Technology (IT) sector for the financial years ranging from 2006 to 2016 were taken. The data used in this study was extracted from the CMIE's Prowess.

The VAICTM was used to measure the intangibility of these firms. The results show thatonly the VAICTM had a significant positive association with profitability of the Indian IT sector, while it had an insignificant relationship with productivity and market valuation. The CEE had a significant positive relationship with productivity and profitability in the IT sector, while, in the case of market valuation, it had an insignificant impact. The HCE had aninsignificant impact on profitability and productivity, while, in the case of market valuation, it had a negative significant impact. The SCE had a significant positive association with market valuation only while it had an insignificant relationship with the productivity and profitability of the Indian IT sector.
\end{abstract}

Keywords: Intellectual Capital, Financial Performance, Value Added Intellectual Coefficient ${ }^{\mathrm{is}}$, Capital Employed Efficiency, Human Capital Efficiency, Structural Capital Efficiency, Profitability, Productivity, Market Valuation.

JEL: C1, C4, C5, G3, Z0 


\section{Introduction}

With the dawn of the 21st century, the information, communications, and computer technologies have undergone swift innovation and popularization, intensely altering human lifestyles and economic configurations. The Internet revolution, which resulted in the transformation of electronic transactions and monetary regimes, has transformed the traditional industrial production process and management style. The digital revolution has initiated a paradigm shift in the production and supply of goods and services, in research and development, design, manufacturing, marketing, and transactions [Hsu, 2001]. In this era, land, labor, and physical capital have been replaced by knowledge, which is considered the most important factor for production [Drucker, 1988]. Different researchers have consensually agreed that knowledge is the decisive factor in this cut-throat, competitive era. Knowledge is also the most important factor in value creation and for a sustainable competitive advantage [Drucker, 1993; Stewart, 1997]. Some of the most successful companies in the world like Apple, Microsoft, Infosys and TATA have successfully managed their knowledge and intellectual capital resources. In today's economy, it has become more important to devise new approaches to understand and measure organizational performance from the perspective of creating value with the knowledge-based assets of the company. When knowledge is measured and reported from a value creation perspective, it is widely known as intellectual capital (IC) [Kianto et al., 2013]. IC is comprised of valuable knowledge based assets / resources and the management activities associated with managing these resources. These assets are mainly intangible in nature and are comprised of various components such as human resources, structural capital, and relational networks, along with the management activities related to strategy making, policy formation and implementation plans to optimally utilize these resources [Bontis, Nikitopoulos, 2001; Edvinsson, Malone, 1997; Guthrie, 2001; Itami, 1991].

The problem that businesses have to deal with is to understand and communicate the difference between the value or market capitalization of a company and its accounting book value [Edvinsson, Malone, 1997]. It can also be assumed that the difference is caused by some undeclared intangible assets and that about $80 \%$ of a company's market value remains unexplained in traditional financial statements [Gu, Lev, 2001]. The rise of the new economy based on information and knowledge has promoted the prominence of intellectual capital. It has become a major construct in explaining the difference between market capitalization and book value [Firer, Stainbank, 2003].

The information technology (IT) sector in India is one of the most promising sectors in terms of growth, contribution to GDP, employment and providing primary services [India Brand Equity Foundation, 2017]. The Indian IT industry is a 150 billion USD industry. It has a share of $9.5 \%$ in the country's GDP, which has grown three fold in the last ten years and a $24 \%$ share in the country's exports, which has increased five times in the last ten years. The IT sector provides 3.5 million direct employment positions and over 10 million indirect employment positions yearly and it is one of the largest organized, private sector employers in India. In the Global Sourcing Market, the top position is occupied by the Indian IT sector, which holds 55\% of the shares [NASSCOM, 2015]. In the service sector, IT companies are identified as intellectual, capital-intensive companies [Alhassan, Asare, 2013; Vale et al., 2016]. Hence, the identifying, reporting, measuring and managing of intellectual capital has become an important task for the management of these organizations [Chen Goh, 2005; Mavridis, 2004a; Mondal, Ghosh, 2012].

Thus, the main goal of this paper is to reveal the existence and nature of the relationship between intellectual capital and financial performance of firms in the IT sector in India. The present analysis is based on a sample of 51 companies listed on the Bombay Stock Exchange (BSE) IT Index.

The remaining parts of this paper include a brief summary of the relevant literature (2), objectives of the study (3), methodology (4), data analysis (5), resultsand discussion (6), conclusion (7) and limitations and future research (8).

\section{Literature Review}

The term, intellectual capital, has been defined by different researchers in many ways. Some of these definitions are as follows:
Author Definition

Mouritsen et al. (2002)

IC is not a conventional accounting or economic term. It may be an effect, it may be a departmental strategy, it may be a mathematical formula

Stewart (1997)

Any intellectual material - knowledge, information, intellectual property, experience - that can be put to use to create wealth
Knowledge that can be converted into value

IC "is quite simple the collection of intangible resources and their flows", an intangible resource is "any factor that contributes to the value generating processes of the company" 
Author Definition

IC "as the economic value of two categories of the intangible assets of a company",

Petty, Guthrie (2000) organizational capital and human capital

Rastogi (2003)

IC may be properly viewed as the holistic or meta-level capabilities of an enterprise to coordinate, orchestrate, and deploy its knowledge resources towards creating value in pursuit of its future vision"

In the last two decades, both academic research and managerial practices have shown a growing interest in the field of intellectual capital. The intellectual capital of any company is basically comprised of three main components: human capital, organizational / structural capital and relational capital [Bontis, 1999; Edvinsson, Malone, 1997; Edvinsson, Sullivan, 1996; Roos et al., 1998].

Human capital is defined as the combination of knowledge, skills, experience, and the individual capabilities of a firm's employees [Edvinsson, Malone, 1997; Roos et al., 2001]. Many authors also said that the value of human capital is derived from an employee's competence, attitude and intellectual agility that encompass the ability to innovate and change practices, that reflects on problems and reaches innovative solutions.

Organizational Capital or Structural Capital deals with the structure and information systems that can lead to business intellect. Structural capital is comprised of all types of "knowledge deposits", such as organizational routines, strategies, process handbooks, and databases [Boisot, 2002; Edvinsson, Sullivan, 1996; Ordóñez de Pablos, 2004; Walsh, Ungson, 1991].

The basic distinction between human capital and structural capital is that human capital is the capital that the human resource takes along with them, while structural capital is that which remains in the company when employees go home for the night [Bontis, 2001; Bontis et al., 2000; Curado, 2008; Roos et al., 1998; Stewart, 1997]. Although it is influenced by human capital, structural capital exists objectively and independently from human capital [Chen et al., 2004]. For example, patents are creat- ed by human capital, but after their creation, they belong to the company.

Some authors further divided organizational/structural capital into process capital and innovation capital [Wang, Chang, 2005]. Process capital includes the activities and processes of the firms and the rolesand responsibilities of the employees, whereas innovation capital encompasses the set of technologies and methods that the firm owns [Agostini, Nosella, 2017; Canibano et al., 2000].

Relational Capital captures the value of relationships with those stakeholders who are external to the organization, such as the knowledge of market channels, customers, suppliers and regulatory agencies [Maditinos et al., 2009]. Relational capital includes not only the set of external relationships established by the firm, but also other dimensions such as branding and reputation [Bontis, 1999; Lowendahl, 2005; Sveiby, 1997; Urde, 1999; Wong, Merrilles, 2008]. It is comprised of the knowledge embedded in all the relationships an organization develops, whether with customers, competitors, suppliers, trade associations or governmental bodies [Bontis, 1999].

The measurement of intellectual capital is a difficult task and the main problems associated with it are: (i) the components of IC are qualitative in nature and based on judgments, (ii) the required information is not available to outsiders and (iii) the conversion of qualitative information into quantitative term is very difficult [Clarke et al., 2011]. At the initial stage, only theoretical and qualitative models were available [Ståhle et al., 2011], while later, some empirical models had been developed by different authors with some of them as follows:
Authors

Pulic (2000, 2004)

Stewart (1997)

Gu, Lev (2001)

Corrado et al. (2004)
Models

Value Added Intellectual Coefficient (VAIC ${ }^{\mathrm{rm}}$ )

Calculated Intangible Value (CIV)

Intangible-Driven Earnings (IDE)

Corrado-Hulten-Sichel (CHS) 
From all these models, Ante Pulic's VAIC ${ }^{\mathrm{TM}}$ model is extensively used in research studies because it only uses audited quantitative information, which is publicly available [Chan, 2009b] and that overcomes the basic problems associated with the measurement of IC [Clarke et al., 2011]. Pulic (2004) criticized other IC measurement models because they lack comparability and scope.

Many studies have been conducted to define and measure intellectual capital but it is difficult to measure it successfully in monetary terms. Some of the researchers have applied the VAIC ${ }^{\mathrm{TM}}$ model in order to identify the link between intellectual capital and financial performance of the companies, but the results were not similar in all the studies. Firer and Mitchell Williams (2003) had conducted a study on 75 South African, publicly listed firms and found that human capital efficiency had a negative impact on profitability, productivity, and market valuation but structural capital efficiency had a positive impact on profitability while physical capital had connected positively with market valuation. Shiu (2006) conducted a study in Taiwan and also found similar results where human capital had a negative impact on productivity and market valuation. Chan (2009) had also conducted a study on the Hong Kong Stock Exchange and found that human capital had a negative relationship with productivity, profitability and market valuation, while physical capital had a significant relationship with all these factors. Bollen, Vergauwen and Schnieders (2012) said that all the components of intellectual capital had an indirect relationship with financial performance measures.

On the other hand, Maditinos et al. (2011) had conducted a study on the Athens Stock Exchange and found that human capital efficiency was positively associated with profitability. Ting \& Lean (2009) concluded that human capital efficiency and physical capital efficiency both had a positive significant relationship with profitability. Zeghal \& Maaloul (2010) carried out a study on 300 firms in the UK and found that only physical capital efficiency had a significant influence on the financial and stock market performance of the firms. Chen et al. (2005) in Taiwan found that human capital efficiency and physical capital efficiency had a significant impact onprofitability, productivity, market valuation, and growth, whereas structural capital efficiency had significant impact only on profitability and market valuation. Mavridis (2004) found that human capital efficiency was more important for the performance of banks in Japan when compared to physical capital efficiency. Appuhami (2007) did not find any significant relationship between HCE and capital gains made by investors, although the relationship was a positive one.

Overall, studies using VAIC ${ }^{\mathrm{TM}}$ have given a mixture of results across different countries, industries, and years. For example, where as Chen et al. (2005) concluded that IC is a driver of both firm value and financial performance, Shiu (2006) found only weak relationships between VAIC $^{\mathrm{TM}}$ and performance. In addition, Firir and Mitchell
Williams (2003) and Chan (2009) concluded that firms and investors place greater importance on physical capital over IC, but Appuhami (2007) concluded that in the Thai financial sector, IC is more important. This varying evidence does not lead to an appealing conclusion regarding the relationship between IC and firm performance.

\section{Objectives of the Study}

The objective of the study was drawn from previous studies in the Indian context [Bharathi Kamath, 2008; Mondal, Ghosh, 2012; Pal, Soriya, 2012]. A review of those studies revealed that due to different industrial and geographical settings, the results variedconsiderably. This led to the validation of the impact of IC on the financial performance of IT companies. The following objectives wereframed:

- To measure the impact of intellectual capital on financial performance.

- To check which components of intellectual capital have significant impact or insignificant impact on financial performance?

- To find out the most significant component of intellectual capital in terms of financial performance.

\section{Methodology Development of Hypothesis}

The present study empirically explored this issue by analyzing the impact of the intellectual capital (IC) measure through VAIC ${ }^{\mathrm{m}}$ on commonly used measures of a company's financial performance, namely, ATO, ROE, ROA \& MB, which represent productivity, profitability, and market valuation, respectively.

In this study, the author predicted a positive relationship between financial performance as measured by ATO, $\mathrm{ROA}, \mathrm{ROE} \& \mathrm{MB}$ and the components of IC performance in the Indian IT sector.

The aggregate measure, based on the components of VAIC $^{\mathrm{TM}}$, represents the total measure of IC. In the following hypotheses, the association of this aggregate measure, along with three components of VAIC ${ }^{\mathrm{TM}}$ for each financial indicator, had examined. The three components of VAIC $^{\mathrm{TM}}$ reflect the classification of IC into physical, human and structural capital. On the basis of the reviewed literature, we formulated four major hypotheses, which were broken up further into twelve sub-hypotheses.

H1. The VAIC ${ }^{T M}$ is positively associated with productivity as measured by ATO.

H1a. The CEE is positively associated with productivity as measured by ATO.

H1b. The HCE is positively associated with productivity as measured by ATO.

H1c. The SCE is positively associated with productivity as measured by ATO. 
H2. The VAIC ${ }^{T M}$ is positively associated with profitability as measured by ROA.

$H 2 a$. The CEE is positively associated with profitability as measured by ROA.

H2b. The HCE is positively associated with profitability as measured by ROA.

H2c. The SCE is positively associated with profitability as measured by ROA.

H3. The VAIC ${ }^{T M}$ is positively associated with profitability as measured by ROE.

$H 3 a$. The CEE is positively associated with profitability as measured by ROE.

$H 3 b$. The HCE is positively associated with profitability as measured by ROE.

H3c. The SCE is positively associated with profitability as measured by ROE.

H4. The VAIC ${ }^{T M}$ is positively associated with market valuation as measured by $M B$.
H4a. The CEE is positively associated with market valuation as measured by $M B$.

$H 4 b$. The HCE is positively associated with market valuation as measured by $M B$.

H4c. The SCE is positively associated with market valuation as measured by $M B$.

\section{Sample and Regression Models}

The sample was drawn from the IT sector for which the sectoral index of BSE, namely BSE IT,had been selected. In all 51 companies of the Information Technology (IT) sector, data from the financial years ranging from 2006 to 2016 had been taken. The data used in this study had been extracted from the CMIE's Prowess.

Model 1 to Model 8 examines the relationship between ATO, ROA, ROE \& MB and the components of VAIC ${ }^{\mathrm{TM}}$. In order to examine the impact of productivity on profitability and market valuation, ATO (measure of productivity) was also used as a control variable in all the models, except those in which ATO itself acts as a dependent variable. These models are illustrated in the following regression equations:

\section{Model Regression Equations}

\begin{tabular}{|c|c|}
\hline 1 & $\mathrm{ATO}=\alpha+\beta 1 \mathrm{VAICTM}^{\mathrm{TM}}+\beta 2 \mathrm{PC}+\beta 3 \log$ total \\
\hline 2 & $\mathrm{ATO}=\alpha+\beta 1 \mathrm{CEE}+\beta 2 \mathrm{HCE}+\beta 3 \mathrm{SCE}+\beta 4 \mathrm{PC}+\beta 5 \log$ total assets $+\mu$ \\
\hline 3 & $\mathrm{ROA}=\alpha+\beta 1 \mathrm{VAICTM}^{\mathrm{TM}}+\beta 2 \mathrm{ATO}+\beta 3 \mathrm{PC}+\beta 4 \log$ total assets $+\mu$ \\
\hline 4 & $\mathrm{ROA}=\alpha+\beta 1 \mathrm{CEE}+\beta 2 \mathrm{HCE}+\beta 3 \mathrm{SCE}+\beta 4 \mathrm{ATO}+\beta 5 \mathrm{PC}+\beta 6 \log$ total assets $+\mu$ \\
\hline 5 & $\mathrm{ROE}=\alpha+\beta 1 \mathrm{VAICTM}^{\mathrm{TM}}+\beta 2 \mathrm{ATO}+\beta 3 \mathrm{PC}+\beta 4 \log$ total assets $+\mu$ \\
\hline 6 & $\mathrm{ROE}=\alpha+\beta 1 \mathrm{CEE}+\beta 2 \mathrm{HCE}+\beta 3 \mathrm{SCE}+\beta 4 \mathrm{ATO}+\beta 5 \mathrm{PC}+\beta 6 \log$ total assets $+\mu$ \\
\hline 7 & $\mathrm{MB}=\alpha+\beta 1 \mathrm{VAICTM}^{\mathrm{TM}}+\beta 2 \mathrm{ATO}+\beta 3 \mathrm{PC}+\beta 4 \log$ total assets $+\mu$ \\
\hline 8 & $\mathrm{MB}=\alpha+\beta 1 \mathrm{CEE}+\beta 2 \mathrm{HCE}+\beta 3 \mathrm{SCE}+\beta 4 \mathrm{ATO}+\beta 5 \mathrm{PC}+\beta 6 \log$ total assets $+\mu$ \\
\hline
\end{tabular}

\section{Definitions of Variables}

Measure of dependent variables: Financial performance indicators are considered as the best indicators to reflect the fulfillment of a business entity's economic goals. Many researchers have used different financial indicators in their studies with some as follows:

\begin{tabular}{lc}
\hline Authors & Variables \\
\hline Firer, Mitchell Williams (2003) & ROA, ATO, MB \\
\hline Gan, Saleh (2008) & ROA, ATO, MB \\
\hline Ghosh, Mondal (2009) & ROA, ATO, MB \\
\hline Mehralian et al. (2012) & ROA, ATO, MB \\
\hline Chen et al. (2005) & ROE, ROA, GR, EP \\
\hline Chu et al. (2011) & ATO, ROA, ROE, MB \\
\hline
\end{tabular}

In order to conduct the study, the four dependent variables of ATO, ROA, ROE and MB were used as a proxy measure designed to capture the respective properties of profitability, productivity, and market valuation.

Asset Turnover Ratio (ATO): this is used to measure the productivity of banks, which is computed by dividing the income of banks by the total funds employed.

Return on Assets (ROA): gives an idea as to how efficient management is at using its assets to generate earnings.

Return on Equity (ROE): measured as the ratio between the net incomes (minus preference dividends) divided by the book value of the total equity, it shows the earnings available to the equity shareholders and is generally considered an important financial indicator for investors.

Market to Book Ratio (MB): ratio of the total market capitalization (share price times number of outstanding common shares) to the book value of net assets. 
Measure of independent variables: The $\mathrm{VAIC}^{\mathrm{TM}}$ Pulic (2000) is an analytical procedure designed to enable management, shareholders and other relevant stakeholders to effectively monitor and evaluate the efficiency of the VA by using a firm's total resources and each major resource component. Actually, VAIC $^{\mathrm{TM}}$ is a composite sum of three separate indicators:

Capital Employed Efficiency (CEE) - indicates how much new value has been created by one invested unit of capital employed.

Human Capital Efficiency (HCE) - shows how much value added has been created by one money unit invested in the employees.

Structural Capital Efficiency (SCE) - indicates the share of SC in the created value.

The following equation formalizes the relationship algebraically:

$\mathrm{CEE}+\mathrm{HCE}+\mathrm{SCE}=\mathrm{VAIC}^{\mathrm{rm}}$.

The total value added is the difference betweenthe output and input in the organization.

$\mathrm{VA}=\mathrm{W}+\mathrm{I}+\mathrm{T}+\mathrm{NI}$.

Where,

$\mathrm{W}=$ Wages and Salaries.

$\mathrm{I}=$ Interest expenses.

$\mathrm{T}=$ Taxes paid.

$\mathrm{NI}=$ Profit after tax.

$\mathrm{CEE}=\mathrm{VA} / \mathrm{CE}$.

$\mathrm{VA}=$ Value added.

$\mathrm{CE}=$ Capital employed.

$\mathrm{HCE}=\mathrm{VA} / \mathrm{HC}$.

$\mathrm{VA}=$ Value added.

$\mathrm{HC}=$ Human capital.
SCE $=$ SC/VA

$\mathrm{VA}=$ Value added.

$\mathrm{SC}=$ Structural capital $=$ VA - HC .

Measure of control variables:

Physical capacity (PC): measures the physical intensity of the companies i.e. how many fixed assets there are in proportion to the total assets. It is calculated as:

$\mathrm{PC}=$ Fixed assets / Total assets.

Natural log (Total Assets): is employed as the proxy for the size of the firm:

Total Assets $=$ Log $($ Total Assets $)=$ Firm size .

\section{Methodology}

The analysis was carried out by a panel data regression that had been conducted by using Stata 13.0. The estimators are BLUE and all the assumptions of CLRM were fulfilled. The full results can be provided on request.

\section{Data Analysis}

\section{Descriptive Statistics}

Table I presents the mean and standard deviation of the dependent variables, independent variables and control factors of the IT sector for the whole study period of 2006-2016. The results show that the ATO had an average of $91 \%$ with an SD of $400 \%$, whereas the ROA had an average of only $10 \%$ with the SD at $21 \%$. The ROE had an average of $11 \%$ with an SD of $123 \%$. The CEE and SCE both had averages of $62 \%$ and $41 \%$ with an SD of $61 \%$ and $91 \%$ respectively. In the case of the minimum and maximum values, some variables such as VAIC ${ }^{\mathrm{TM}}$, ATO, $\mathrm{MB}, \mathrm{HCE}$ and PC showed a remarkable variation. Only the ROA showed some consistency while the rest of the variables were otherwise inconsistent.

Table I. Descriptive statistics for selected variables from the IT sector

\begin{tabular}{|c|c|c|c|c|c|}
\hline Variable & Obs & Mean & Std. Dev & Min & $\operatorname{Max}$ \\
\hline ATO & 561 & .9192448 & 4.099524 & -26.28223 & 92.95547 \\
\hline $\mathrm{ROA}$ & 561 & .1048047 & .2140106 & -3.516358 & 1.284027 \\
\hline ROE & 561 & .1175492 & 1.234371 & -27.77705 & 4.254427 \\
\hline MB & 561 & 3.255526 & 9.532208 & -118 & 56.57 \\
\hline CEE & 561 & .6210386 & .6128962 & -5.215329 & 3.119576 \\
\hline $\mathrm{HCE}$ & 561 & 1.529035 & 6.271753 & -113.9556 & 28.0516 \\
\hline SCE & 561 & .4151664 & .9105643 & -9.965094 & 13.64391 \\
\hline VAIC $^{\mathrm{TM}}$ & 561 & 2.56524 & 6.417243 & -112.9729 & 29.72279 \\
\hline PC & 561 & .9316743 & 18.19509 & -.0379837 & 431.1125 \\
\hline LTA & 561 & 8.706287 & 1.869 & .4700036 & 13.57093 \\
\hline
\end{tabular}


Table II. Spearman Correlations - independent and dependent variables of the IT sector

\begin{tabular}{|c|c|c|c|c|c|c|c|c|c|c|}
\hline & CEE & $\mathrm{HCE}$ & SCE & $\mathbf{V A I C}^{\mathrm{TM}}$ & ATO & ROA & ROE & MB & PC & LTA \\
\hline CEE & 1.0000 & & & & & & & & & \\
\hline HCE & 0.1217 & 1.0000 & & & & & & & & \\
\hline SCE & -0.0736 & -0.0186 & 1.0000 & & & & & & & \\
\hline VAIC $^{\mathrm{TM}}$ & 0.2040 & 0.9863 & 0.1167 & 1.0000 & & & & & & \\
\hline ATO & -0.3290 & -0.0022 & -0.0746 & -0.0442 & 1.0000 & & & & & \\
\hline ROA & 0.3356 & 0.2273 & 0.0080 & 0.2553 & 0.0999 & 1.0000 & & & & \\
\hline ROE & 0.1489 & 0.0886 & -0.0371 & 0.0955 & 0.0384 & 0.2211 & 1.0000 & & & \\
\hline MB & 0.0571 & -0.0707 & 0.1015 & -0.0493 & -0.0081 & 0.0534 & 0.0161 & 1.0000 & & \\
\hline PC & -0.4026 & -0.0071 & -0.0697 & -0.0552 & 0.9496 & -0.1505 & 0.0032 & -0.0102 & 1.0000 & \\
\hline Lta & 0.1179 & 0.1396 & 0.0643 & 0.1568 & -0.1497 & 0.2057 & 0.0023 & 0.1039 & -0.1873 & 1.0000 \\
\hline
\end{tabular}

\section{Correlation analysis}

To find out the intensity of the relationship among all the variables of the IT sector, the correlation coefficient was estimated along with its significance and this is depicted in Table II.

In Table II the capital employed efficiency shows a positive correlation with profitability and market to book value while it is negatively correlated with productivity. Human capital efficiency and structural capital efficiency are also negatively correlated with productivity, whereas HCE isnegatively correlated andSCE ispositively correlated with the market to book ratio.

\section{Multiple Regression Results}

Table 1. Regression Results for ATO - VAIC ${ }^{\mathrm{TM}}$

\begin{tabular}{|c|c|c|c|c|}
\hline & \multicolumn{4}{|c|}{$\mathrm{IT}$} \\
\hline Variable & $\mathrm{C}$ & $\mathrm{VAIC}^{\mathrm{TM}}$ & $\mathrm{PC}$ & LTA \\
\hline Coefficient & .166523 & .002633 & .215207 & .062651 \\
\hline Std Error & .263855 & .008558 & .003034 & .029870 \\
\hline t-Statistics & 0.63 & 0.31 & 70.91 & 2.10 \\
\hline Probability & 0.528 & 0.758 & $0.000 * *$ & $0.036^{*}$ \\
\hline
\end{tabular}

Notes: (i) Adjusted $\mathrm{R}^{2}=0.9020$.

(ii) ${ }^{\star}$ Significant at $\alpha=0.95$.

(iii) ${ }^{*}$ Significant at $\alpha=0.99$.

Source: Computed by the authors.
Table 2. Regression Results for ROA - VAIC ${ }^{\mathrm{TM}}$

\begin{tabular}{|c|c|c|c|c|}
\hline \multicolumn{5}{|c|}{ IT } \\
\hline Variable & $\mathrm{C}$ & VAIC $^{\mathrm{TM}}$ & $\mathrm{PC}$ & LTA \\
\hline Coefficient & -.062567 & .007530 & -.001294 & .017144 \\
\hline Std Error & .041743 & .001354 & .000480 & .004725 \\
\hline t-Statistics & -1.50 & 5.56 & -2.70 & 3.63 \\
\hline Probability & 0.134 & $0.000 * *$ & $0.007 *$ & $0.000 * *$ \\
\hline
\end{tabular}

Notes: (i) Adjusted $\mathrm{R}^{2}=0.1002$.

(ii) ${ }^{\star}$ Significant at $\alpha=0.95$.

(iii) ${ }^{*}$ Significant at $\alpha=0.99$.

Source: Computed by the authors.

Table 3. Regression Results for ROE - VAIC ${ }^{\mathrm{TM}}$

\begin{tabular}{|c|c|c|c|c|}
\hline \multicolumn{5}{|c|}{ IT } \\
\hline Variable & $\mathrm{C}$ & VAIC $^{\mathrm{TM}}$ & $\mathrm{PC}$ & LTA \\
\hline Coefficient & .13704 & .018803 & .000431 & -.007825 \\
\hline Std Error & .253311 & .008216 & .002913 & .028676 \\
\hline $\mathrm{t}$-Statistics & 0.54 & 2.29 & 0.15 & -0.27 \\
\hline Probability & 0.589 & $0.022^{*}$ & 0.882 & 0.785 \\
\hline
\end{tabular}

Notes: (i) Adjusted $\mathrm{R}^{2}=$.

(ii) ${ }^{\star}$ Significant at $\alpha=0.95$.

(iii) ${ }^{*}$ Significant at $\alpha=0.99$.

Source: Computed by the authors. 
Table 4. Regression Results for MB - VAICTM

\begin{tabular}{|c|c|c|c|c|}
\hline & \multicolumn{4}{|c|}{ IT } \\
\hline Variable & $\mathrm{C}$ & $\mathrm{VAIC}^{\mathrm{TM}}$ & PC & LTA \\
\hline Coefficient & -1.636278 & -.099530 & .004092 & .590758 \\
\hline Std Error & 1.950299 & .0632617 & .022432 & .220786 \\
\hline $\mathrm{t}$-Statistics & -0.84 & -1.57 & 0.18 & 2.68 \\
\hline Probability & 0.402 & 0.116 & 0.855 & $0.008^{\star}$ \\
\hline
\end{tabular}

Notes: (i) Adjusted $\mathrm{R}^{2}=0.0099$.

(ii) ${ }^{*}$ Significant at $\alpha=0.95$.

(iii) ${ }^{\star *}$ Significant at $\alpha=0.99$.

Source: Computed by the authors.

Table 5. Regression Results for ATO - CEE, HCE, SCE

\begin{tabular}{|c|c|c|c|c|c|c|}
\hline \multirow{2}{*}{ Variables } & \multicolumn{6}{|c|}{ IT } \\
\hline & $\mathrm{C}$ & $\mathrm{CEE}$ & HCE & SCE & PC & LTA \\
\hline Coefficient & -.060560 & .419733 & -.004475 & -.016072 & .220739 & .060530 \\
\hline Std Error & .265911 & .096636 & .008668 & .059259 & .003267 & .029442 \\
\hline $\mathrm{t}$-Statistics & -0.23 & 4.34 & -0.52 & -0.27 & 67.55 & 2.06 \\
\hline Probability & 0.820 & $0.000^{* *}$ & 0.606 & 0.786 & $0.000^{\star *}$ & $0.040^{\star}$ \\
\hline Adj. $\mathrm{R}^{2}$ & 0.9050 & & & & & \\
\hline F-statistics & 1067.77 & & & & & \\
\hline
\end{tabular}

Notes: (i) ${ }^{\star}$ Significant at $\alpha=0.95$.

(ii) ${ }^{*}$ Significant at $\alpha=0.99$.

Source: Computed by the authors.

Table 6. Regression Results for ROA - CEE, HCE, SCE

\begin{tabular}{|c|c|c|c|c|c|c|}
\hline & \multicolumn{6}{|c|}{ IT } \\
\hline Variables & $\mathrm{C}$ & $\mathrm{CEE}$ & $\mathrm{HCE}$ & SCE & PC & LTA \\
\hline Coefficient & -.115972 & .104575 & .005837 & .005604 & 6.840507 & .016606 \\
\hline Std Error & .041226 & .014982 & .001343 & .009187 & .000506 & .004564 \\
\hline $\mathrm{t}$-Statistics & -2.81 & 6.98 & 4.34 & 0.61 & 0.00 & 3.64 \\
\hline Probability & 0.005 & $0.000^{* *}$ & $0.000^{\star *}$ & 0.542 & 0.999 & $0.000^{* *}$ \\
\hline Adj. $\mathrm{R}^{2}$ & 0.1619 & & & & & \\
\hline F-statistics & 22.64 & & & & & \\
\hline
\end{tabular}

Notes: (i) *Significant at $\alpha=0.95$.

(ii) ${ }^{\star *}$ Significant at $\alpha=0.99$.

Source: Computed by the authors. 
Table 7. Regression Results for ROE - CEE, HCE, SCE

\begin{tabular}{|c|c|c|c|c|c|c|}
\hline \multicolumn{7}{|c|}{$\mathrm{IT}$} \\
\hline Variables & $\mathrm{C}$ & CEE & HCE & SCE & PC & LTA \\
\hline Coefficient & -.030009 & .337991 & .013816 & -.024186 & .004575 & -.008924 \\
\hline Std Error & .256700 & .093289 & .008368 & .057206 & .003154 & .028422 \\
\hline t-Statistics & -0.12 & 3.62 & 1.65 & -0.42 & 1.45 & -0.31 \\
\hline Probability & 0.907 & $0.000^{* *}$ & 0.099 & 0.672 & 0.147 & 0.754 \\
\hline
\end{tabular}

Adj. $R^{2}$

F-statistics

Notes: (i) *Significant at $a=0.95$.

(ii) ${ }^{\star *}$ Significant at $\alpha=0.99$.

Source: Computed by the authors.

Table 8. Regression Results for MB - CEE, HCE, SCE

\begin{tabular}{|c|c|c|c|c|c|c|}
\hline \multicolumn{7}{|c|}{ IT } \\
\hline Variables & $\mathrm{C}$ & CEE & HCE & SCE & PC & LTA \\
\hline Coefficient & -2.686508 & 1.297723 & -.142856 & 1.071703 & .026447 & .561083 \\
\hline Std Error & 1.981643 & .720162 & .064598 & .441615 & .024351 & .219415 \\
\hline t-Statistics & -1.36 & 1.80 & -2.21 & 2.43 & 1.09 & 2.56 \\
\hline Probability & 0.176 & 0.072 & $0.027^{\star}$ & $0.016^{*}$ & 0.278 & $0.011^{\star}$ \\
\hline Adj. $R^{2}$ & 0.0240 & & & & & \\
\hline F-statistics & 0.0024 & & & & & \\
\hline
\end{tabular}

Notes: (i) *Significant at $\alpha=0.95$.

(ii) ${ }^{* *}$ Significant at $\alpha=0.99$.

Source: Computed by the authors.

\section{Results \& Discussion}

The present study measured the intellectual capital performance of the IT sector in India. VAIC ${ }^{\mathrm{TM}}$ was applied to a sample of 51 companies from the BSE IT index for a period of 11 years from 2006-2016. The findings suggest that VAIC $^{\mathrm{TM}}$ has an insignificant impact on the productivity of the IT sector as reported by Ghosh \& Mondal (2009), Kamath (2008) and Pal \& Soriya (2012). Intellectual capital had a positive significant impact on the profitability of the IT sector, which is similar to some previous studies [Chu et al., 2011; Pal, Soriya, 2012]. Intellectual capital also had an insignificant impact on market valuation. Many previous studies also failed to establish any significance between intellectual capital and market value [Gan, Saleh, 2008; Maria Morariu, 2014]. Intellectual capital is the main cause for the difference between the mar- ket value and book value of the company. Thus, overall, VAIC $^{\mathrm{TM}}$ was found to have a significant positive influence on profitability only, but not on productivity and market valuation.

In order to understand the relationship of the individual components of $\mathrm{VAIC}^{\mathrm{TM}}$ with the financial performance of the IT sector, the model was further analyzed and the findings suggested that CEE had a significant positive relationship with the productivity and profitability of the IT sector [Gan, Saleh, 2008; Chu et al., 2011] but in the case of market valuation, it had an insignificant association. The HCE had a significant positive association with the ROA, but not with ROE [Gan, Saleh, 2008]. In the case of productivity, it had an insignificant impact; while in the case of market valuation, the HCE had a significant negative impact on the IT sector. This indicates that IT 
companies prefer to employ more physical and financial assets, rather than human assets. While in the case of the IT sector, the negative significance of HCE with MB shows that investors perceived expenses spent on employees as a cost rather than as an investment. Chu et al. (2011) also had similar results.

The statistical association between SCE and MB was positively significant [Chu et al., 2011], while it had an insignificant impact on the productivity of the IT sector [Gan, Saleh, 2008; Maria Morariu, 2014]. The SCE had an insignificant impact on the profitability of the IT sector [Gan, Saleh, 2008; Mondal, Ghosh, 2012]. This had been expected, as the SCE had an inverse relationship with HCE [Pulic, 2000]. Some of the previous studies had failed to establish the significance of SCE on financial performance [Firer, Mitchell Williams, 2003]. The present study gave quite significant results for SCE as a moderate predictor as a measure of the financial conditions of a business. This is completely against the concept regarding the inappropriateness of VAIC ${ }^{\mathrm{TM}}$ methodology for computation of SCE, which is considered as one of the major limitations of VAIC ${ }^{\mathrm{TM}}$ technique [Ståhle et al., 2011].

In the case of the control variables, PC showed an insignificant impact in most of the models, while the LTA was significant in almost all the models. All the regression results were based on Pooled OLS regression except the impact of VAIC ${ }^{\mathrm{TM}}$ on ROE (Table 3 and 7) in the IT sector, which used the Random - effects GLS regression. All the methods of regression were based upon the results of Hausman Test and Breusch- Pagan Lagrangian multiplier test. Spearman's correlation (Table II) clearly shows that there was a problem of multicollinearity between the two control variables ATO and PC in the IT sector. The Breusch-Pagan test had been used to check the homoscedasticity of the data and as in most cases, the data was found to be heteroscedastic, but the problem was resolved with the help of the Robust standard error. The Wooldridge test for autocorrelation showed that the problem of autocorrelation was also present in a few cases, which had been resolved by the help of the Prais-Winsten test. All the estimators were BLUE and fulfilled all the assumptions of CLRM.

\section{Conclusion}

The present study contributes to the literature in the following ways. Firstly, it employed updated data from 2016, which had not been used so far. Secondly,the study wasconducted on an IT sector that is considered among the most promising sectors in terms of growth, contribution to GDP, employment and providing primary services. Thirdly, the sample selection was based on the index of BSE, which had not been studied earlier. Finally, this study rejected the arguments of many authors regarding the calculation of $\mathrm{HC}$ and $\mathrm{SC}$ in $\mathrm{VAIC}^{\mathrm{m}}$ that causes multicollinearity between HCE and SCE, and the insignificant impact of SCE on financial performance [Nazari, Herremans, 2007; Ståhle et al., 2011].
The results of this study show that the concept of intellectual capital or value creation by using knowledge is not being valued or given importance by the knowledge driven industries in India. In order to conduct the study, the BSE IT index was taken as a sample from 2006 to 2016. CEE was found to be the best predictor among all the components of VAIC ${ }^{\mathrm{TM}}$, except for market valuation, which had a significant positive relationship with all other measures of financial performance. This indicates that the performance of a firm is still being perceived in terms of tangible assets, even in the case of knowledge based industries. This idea is absolutely opposite the argument of many scholars that intellectual capital is more important for knowledge driven enterprises because it helps them in acquiring a competitive advantage [Marr, Chatzkel, 2004]. According to the traditional view of productivity, as the number of employees is increasing with the other factors remaining the same, the marginal output starts diminishing. In contrast, from the value creation perspective, human capital may be looked upon as a depository of knowledge. The pool of knowledge contained in humans becomes IC for value creation, contributing to the enhancement of a company's overall productivity [Pulic, 2000]. The insignificance of HCE with productivity may be because traditional accounting practices do not give due consideration to measuring the value created by human capital. The insignificant relation of HCE with financial performance measures may be because of the inability of the companies to extract the full potential of their employees, as it seems that human resources aredevoid of proper training, development and management. It has been expected and proved by many previous studies that human capital efficiency should be higher than physical and structural capital efficiency [Goh, 2005].

The insignificant impact of SCE on the productivity and profitability of IT is similar to many earlier studies [Ghosh, Maji, 2015]. It also indicates that managers must be responsible for the optimum utilization of the structural resources in order to achieve the desired profitability and productivity, especially in the case of IT industries. The insignificant impact of $\mathrm{VAIC}^{\mathrm{TM}}$ on $\mathrm{MB}$ shows that an average Indian investor does not consider intellectual capital while making decisions regarding investments. One of the major reasons behind this tendency might be the non-disclosure of intellectual capital on the financial statements of companies.

The VAIC ${ }^{\mathrm{m}}$ model has been criticized regarding the calculation of HC and SC in this model. HC and SC are very much similar to each other and this leads to the problem of multicollinearity between HCE and SCE [Ståhle et al., 2011]. The correlation coefficients between HCE and SCE in Table II are very low and there is no multicollinearity between them. The general perception regarding the insignificant impact of SCE on measures of financial performance [Nazari, Herremans, 2007] is also not applicable because SCE has a significant impact on the market valuation of the IT sector. 


\section{Limitations and Future Research}

The main limitation of this study was that the time period of a decade was very long during which time the structure of the companies generally kept changing, which affects the analysis of the companies. The use of $\mathrm{MB}$ as the market valuation also fell under a grey area because investors might not always consider financial statements before investing; in fact, major decisions have been made under the influence of news and information. Structural capital should also be clearly defined as to whether it would be technology or plans and procedures that can achieve profitability. Another problem was with data since some companies had to be dropped due to the unavailability of the data.

Therefore, future studies could be conducted with a different IC measurement model for a shorter duration of time or the results of VAIC ${ }^{\mathrm{TM}}$ couldbe compared with other IC efficiency measures. Human capital could be calculated with data generated from some other means rather than by extracting it from financial statements.

\section{References}

Agostini, L., Nosella, A. (2017). Enhancing radical innovation performance through intellectual capital components. Journal of Intellectual Capital, 18(4), pp. 789-806. URL: https://doi.org/10.1108/JIC-10-2016-0103

Alhassan, A.L., Asare, N. (2013) Intellectual capital and bank productivity in emerging markets: evidence from Ghana. Management Decision, 54(3), pp. 589-609. URL: https://doi.org/10.1108/MD-01-2015-0025

Appuhami, R. (2007) The impact of intellectual capital on investors' capital gains on shares: an empirical investigation of Thai banking, finance \& insurance sector. International Management Review, 3(2), pp. 14-25.

Bharathi Kamath, G. (2008) Intellectual capital and corporate performance in Indian pharmaceutical industry. Journal of Intellectual Capital, 9(4), pp. 684-704. URL: https://doi.org/10.1108/14691930810913221

Boisot, M. (2002) The creation and sharing of knowledge. In: C. Choo \& N. Bontis (Eds.), The Strategic Managment of Intellectual Capital and Organizational Learning. Oxford: Oxford University Press.

Bollen, L., Vergauwen, P., Schnieders, S. (2012) Linking intellectual capital and intellectual property to company performance. Management Decision, 43(9), pp. 11611185. URL: https://doi.org/10.1108/00251740510626254

Bontis, N. (1999) Managing organisational knowledge by diagnosing intellectual capital framing and advancing the state of the field. International Journal of Technology Management, 18(5/6/7/8), pp. 433-463.

Bontis, N. (2001) Assessing knowledge assets: a review of the models used to measure intellectual capital. International Journal of Management Reviews, 3(1), pp. 41-60.
Bontis, N., Keow, W., \& Richardson, S. (2000) Intellectual capital and business performance in Malaysian industries. Journal of Intellectual Capital, 1(1), pp. 85-100. URL: https://doi.org/10.1108/14691930010324188

Bontis, N., Nikitopoulos, D. (2001) Thought leadership on intellectual capital. Journal of Intellectual Capital, 2(3), pp. 183-191. URL: https://doi. org/10.1108/14691930110400182

Canibano, L., Garcia-Ayuso, M., Sanchez, P. (2000) Accounting for intangibles: a literature review. Journal of Accounting Literature, 19, pp. 102-130.

Chan, K. H. (2009a). Impact of intellectual capital on organizational performance: An empirical study of companies in the Hang Seng Index (Part 1). The Learning Organization, 16(1), pp. 4-21.

Chan, K.H. (2009b) Impact of intellectual capital on organizational performance. An empirical study of companies in the Hang Seng Index (Part 2). The Learning Organization, 16(1), pp. 22-39.

Chen, J., Zhu, Z., Yuan Xie, H. (2004) Measuring intellectual capital: a new model and empirical study. Journal of Intellectual Capital, 5(1), pp. 195-212. URL: https://doi.org/10.1108/14691930410513003

Chen, M., Cheng, S., Hwang, Y. (2005)

An empirical investigation of the relationship between intellectual capital and firms' market value and financial performance. Journal of Intellectual Capital, 6(2), pp. 159-176. URL:

https://doi.org/10.1108/14691930510592771

Chen Goh, P. (2005) Intellectual capital performance of commercial banks in Malaysia. Journal of Intellectual Capital, 6(3), pp. 385-396. URL: https://doi. org/10.1108/14691930510611120

Clarke, M., Seng, D., Whiting, R. H. (2011) Intellectual capital and firm performance in Australia. Journal of Intellectual Capital, 12(4), pp. 505-530. URL: https:/doi. org/10.1108/14691931111181706

Corrado, C., Hulten, C., Sichel, D. (2004) Measuring capital and technology: an expanded framework, 2004-65. Washington, D.C.

Curado, C. (2008) Perceptions of knowledge management and intellectual capital in the banking industry. Journal of Knowledge Management, 12(3), pp. 141-155.

Drucker, P.F. (1988) The coming of the new organization. Harvard Business Review, 66(1), pp. 45-53.

Drucker, P.F. (1993) The Post Capitalist Society. New York: Harper Business.

Edvinsson, L., Malone, M.S. (1997) Intellectual Capital: The Proven Way to Establish Your Company's Real Value by Measuring its Hidden Brainpower. London: PIATKUS BOOKS. 
Edvinsson, L., Sullivan, P.H. (1996) Developing a Model for Managing Intellectual Capital. European Management Journal, 14(4), pp. 356-364.

Firer, S., Mitchell Williams, S. (2003) Intellectual capital and traditional measures of corporate performance. Journal of Intellectual Capital, 4(3), pp. 348-360. URL: https://doi.org/10.1108/14691930310487806

Firer, S., Stainbank, L. (2003) Testing the relationship between intellectual capital and a company's performance: evidence from South Africa. Meditari Accountancy Research, 11(1), pp. 25-44.

Gan, K., Saleh, Z. (2008) Intellectual capital and corporate performance of technology-intensive companies: Malaysia evidence. Asian Journal of Business and Accounting, 1(1), pp. 113-130.

URL: https://doi.org/10.1108/14691930010324188

Ghosh, S.K., Maji, S.G. (2015) Empirical Validity of Value Added Intellectual Coefficient Model in Indian Knowledge-based Sector. Global Business Review, 16(6), pp. 947-962.

URL: https://doi.org/10.1177/0972150915597597

Ghosh, S., Mondal, A. (2009) Indian software and pharmaceutical sector IC and financial performance. Journal of Intellectual Capital, 10(3), pp. 369-388. URL: https://doi.org/10.1108/14691930910977798

Gu, F., Lev, B. (2001) Intangible assets: measurement, drivers, usefulness. New York.

Guthrie, J. (2001) The management, measurement and the reporting of intellectual capital. Journal of Intellectual Capital, 2(1), pp. 27-41. URL: https://doi.org/10.1108/14691930110380473

Hsu, G.H.Y. (2001) Knowledge-based economies and competition policy: developmentalstrategy concerning the liberalization and internationalization of Taiwan's business. Fair Trade Quaterly, 4(9), pp. 123-136.

India Brand Equity Foundation (2017) IT \& ITeS Industry in India. Retrieved from 05/07/2017

Itami, H. (1991) Mobilizing Invisible Assets. Massachusetts: Harvard University Press.

Kai Wah Chu, S., Hang Chan, K., Wu, W.W.Y. (2011) Charting intellectual capital performance of the gateway to China. Journal of Intellectual Capital, 12(2), pp. 249-276. URL:

https://doi.org/10.1108/14691931111123412

Kianto, A., Andreeva, T., Pavlov, Y. (2013) The impact of intellectual capital management on company competitiveness and financial performance. Knowledge Management Research \& Practice, 11(2), pp. 112-122. URL: https://doi.org/10.1057/kmrp.2013.9

Lowendahl, B. (2005) Strategic Management of Professional Service Firms. Copenhagen: Copenhagen Business School Press.
Maditinos, D., Chatzoudes, D., Tsairidis, C., Theriou, G. (2011) The impact of intellectual capital on firms' market value and financial performance. Journal of Intellectual Capital, 12(1), pp. 132-151.

URL: https://doi.org/10.1108/14691931111097944

Maditinos, D., Mandilas, A. A., Gstraunthaler, T., \& Alonso, A. P. (2009). Does Intellectual Capital Aff ect Corporate Performance? New Perspectives on Sustainability, pp. 16-22.

Maria Morariu, C. (2014) Intellectual capital performance in the case of Romanian public companies. Journal of Intellectual Capital, 15(3), pp. 392-410. URL: https://doi.org/10.1108/JIC-05-2014-0061

Marr, B., Chatzkel, J. (2004) Intellectual capital at the crossroads: managing, measuring, and reporting of IC. Journal of Intellectual Capital, 5(2), pp. 224-229. URL: https://doi.org/10.1108/14691930410533650

Mavridis, D. G. (2004a). The intellectual capital performance of the Japanese banking sector. Journal of Intellectual Capital, 5(1), pp. 92-115.

URL: https://doi.org/10.1108/14691930410512941

Mavridis, D. G. (2004b). The intellectual capital performance of the Japanese banking sector. Journal of Intellectual Capital, 5(1), pp. 92-115.

URL: https://doi.org/10.1108/14691930410512941

Mehralian, G., Rajabzadeh, A., Reza Sadeh, M., Reza Rasekh, H. (2012) Intellectual capital and corporate performance in Iranian pharmaceutical industry. Journal of Intellectual Capital, 13(1), pp. 138-158.

URL: https://doi.org/10.1108/14691931211196259

Mondal, A., Ghosh, S.K. (2012) Intellectual capital and financial performance of Indian banks. Journal of Intellectual Capital, 13(4), pp. 515-530. URL: https://doi.org/10.1108/14691931211276115

Mouritsen, J., Bukh, P.N., Larsen, H.T., Johansen, M.R. (2002) Developing and managing knowledge through intellectual capital statements. Journal of Intellectual Capital, 3(1), pp. 10-29.

URL: https://doi.org/10.1108/14691930210412818

NASSCOM (2015). The IT-BPM Sector in India. Strategic Review. New Delhi.

Nazari, J.A., Herremans, I.M. (2007) Extended VAIC model: measuring intellectual capital components. Journal of Intellectual Capital, 8(4), pp. 595-609.

URL: https://doi.org/10.1108/14691930710830774

Ordóñez de Pablos, P. (2004) Measuring and reporting structural capital. Journal of Intellectual Capital, 5(4), pp. 629-647.

URL: https://doi.org/10.1108/14691930410567059

Pal, K., Soriya, S. (2012) IC performance of Indian pharmaceutical and textile industry. Journal of Intellectual Capital, 13(1), pp. 120-137. URL: https://doi.org/10.1108/14691931211196240 
Petty, R., Guthrie, J. (2000) Intellectual capital literature review. Journal of Intellectual Capital, 1(2), pp. 155-176. URL: https://doi.org/10.1108/14691930010348731

Pulic, A. (2000) VAIC ${ }^{\mathrm{TM}}$ - an accounting tool for IC management. Int. J. Technology Management, 20(5/6/7/8).

Pulic, A. (2004) Intellectual capital - does it create or destroy value? Measuring Business Excellence, 8(1), pp. 62-68.

Rastogi, P.N. (2003) The nature and role of IC. Journal of Intellectual Capital, 4(2), pp. 227-248. URL: https://doi. org/10.1108/14691930310472848

Roos, G., Bainbridge, A., Jacobsen, K. (2001) Intellectual capital analysis as a strategic tool. Strategy \& Leadership, 29(4), pp. 21-26.

Roos, J., Roos, G., Dragonetti, N.C., Edvinsson, L. (1998) Intellectual Capital: Navigating in the New Business Landscape. New York: New York University Press.

Shiu, H. (2006) Application of the VAIC ${ }^{\mathrm{TM}}$ method to measures of corporate performance: a quantile regression approach. Journal of American Academy of Business, 8(2), pp. 156-160.

Ståhle, P., Ståhle, S., \& Aho, S. (2011). Value added intellectual coefficient (VAIC): a critical analysis. Journal of Intellectual Capital, 12(4), pp. 531-551. URL: https:// doi.org/10.1108/14691931111181715

Stewart, T. (1997) Intellectual capital: The new wealth of organizations. New York: NY: Doubleday.

Stepanova, A., Rabotinskiy, I. (2014) Corporate governance and cost of debt: review of recent studies // Journal of corporate finance, 2(30), pp. 91-105.
Sveiby, K. (1997) The intangible assets monitor. Journal of Human Resource Costing \& Accounting, 2(1), pp. 73-97.

Urde, M. (1999) Brand orientation: a mindset for building brands into strategic resources. Journal of Marketing Management, 15(1-3), pp. 117-133.

Vale, J., Branco, M.C., Ribeiro, J. (2016) Individual intellectual capital versus collective intellectual capital in a meta-organization. Journal of Intellectual Capital, 17(2), pp. 279-297. URL: https://doi.org/10.1108/JIC-05-20150044

Walsh, J., \& Ungson, G. (1991). Organizational memory. The Academy of Management Review, 16(1), pp. 57-91.

Wang, W., \& Chang, C. (2005). Intellectual capital and performance in causal models. Journal of Intellectual Capital, 6(2), pp. 222-236. https://doi. org/10.1108/14691930510592816

Wei Kiong Ting, I., \& Hooi Lean, H. (2009). Intellectual capital performance of financial institutions in Malaysia. Journal of Intellectual Capital, 10(4), pp. 588-599. https:// doi.org/10.1108/14691930910996661

Wong, H., \& Merrilles, B. (2008). The performance benefits of being brand-orientated. Journal of Product \& Brand Management, 17(6), pp. 372-383.

Zeghal, D., \& Maaloul, A. (2010). Analysing value added as an indicator of intellectual capital and its consequences on company performance. Journal of Intellectual Capital, 11(1), pp. 39-60. 